\title{
Najnovšie didaktické materiály vo vyučovaní sociolingvistiky
}

\author{
Lőrincz Gábor - Istók Vojtech
}

\section{The most recent didactic materials for teaching sociolinguistics Abstract}

Sociolinguistics is a mature linguistic discipline, even though it can be considered relatively new in comparison with other fields of linguistics. However, that does not mean that it is not still evolving. On the contrary, contemporary sociolinguists do not rely only on the notepad and dictation machine anymore, but also the camera, so they may document synchronous moments for the future (Blommaert 2012, 5). This article focuses on presenting various thematic fields of sociolinguistics building on the university textbook of Sándor János Tóth (2019a) with the title Sociolinguistics in a Slovak-Hungarian context. The book came into being within the framework of the project KEGA001UJS-4/2018 and it focuses on the work of Slovak researchers, while it also highlights sociolinguistic questions in the context of the Slovak language and Hungarian language, particularly Hungarian used in Slovakia and Slovak used in Hungary. The reason for compiling this book was that, until now, there was no textbook for university or college education available that would have engaged in the Slovak language (as well) in such an explicit manner. Sándor János Tóth also applied his previous experience gained from his own sociolinguistic research projects (e.g. 2012a, 139-156).

Keywords: sociolinguistics; textbook; education; didactic materials; electronic materials; Slovak-Hungarian context

Kl'účové slová: sociolingvistika; učebnica; edukácia; didaktické materiály; elektronické materiály; slovensko-mad'arský kontext

Subject-Affiliation in New CEEOL: Language and Literature - Applied Linguistics - Sociolinguistics

DOI: 10.36007/eruedu.2021.3.088-096

\section{Úvod}

Sociolingvistika je zrelou jazykovednou disciplínou, aj ked' je relatívne nová v porovnaní s inými oblastami lingvistiky. To však neznamená, že by sa už v dnešnej dobe neformovala, naopak: sociolingvisti sa v súčasnosti neopierajú iba o poznámkový zošit a diktafón, ale použivajú aj fotoaparát, aby vedeli zdokumentovat' synchrónne momenty pre budúcnost' (Blommaert 2012, 5).

Článok sa zameriava na predstavenie rôznych tematických okruhov sociolingvistiky na základe vysokoškolskej učebnice Sándora Jánosa Tótha (2019a) s názvom Sociolingvistika v slovensko-mad'arskom kontexte. Kniha 
vznikla v rámci riešenia projektu KEGA001UJS-4/2018, je zameraná na práce slovenských výskumníkov a pritom kladie dôraz aj na sociolingvistické otázky v kontexte slovenského a mad'arského jazyka, presnejšie mad'arčiny použivanej na Slovensku a slovenčiny použivanej v Mad'arsku. Pričinou zostavenia knihy bolo, že učebnica sociolingvistiky, ktorá by sa zaoberala (aj) slovenským jazykom doteraz nebola dostupná v takej explicitnej forme pre vysokoškolské a univerzitné štúdium. Sándor János Tóth sa pritom opieral aj o svoje predchádzajúce skúsenosti z vlastných sociolingvistických výskumov (napr. Tóth 2012a, 139 - 156).

\section{Štruktúra a obsah knihy Sociolingvistika v slovensko-mad'ars- kom kontexte (Tóth 2019a)}

Kniha sa člení na devät' kapitol. Autor v predslove poukazuje na to, že sa nechal koncepčne inšpirovat' inými univerzitnými učebnicami, ktoré súvisia aj so sociolingvistikou (napr. Kováčová, 2013). Každá kapitola sa delí na d'alšie dve časti: v prvej (A) sa nachádzajú prednášky spojené s jednotlivými oblastami sociolingvistiky, a v druhej (B) sa uvádzajú ukážky zo štúdií, resp. výsledkov výskumov z daných oblastí. Teoretické časti (Vstup do problematiky) referujú stručne a heslovite o danej téme, z čoho vyplýva, že môžu tvorit' iba kostru jednotlivých prednášok, ale napriek tomu sa svojím heslovitým štýlom podobajú prezentáciám, z ktorých sa poslucháči radi učia. Praktické časti ( $Z$ výskumov) zahŕňajú úryvky, pomocou ktorých sú teoretické poznatky efektívnejšie znázornené. Autor o tom píše nasledovne: „Učebnica obsahuje široký záber tém zo spektra sociolingvistiky, ponecháme na pedagógov, ktorú z nich zaradia do svojho plánu vyučovania, v závislosti od detailnosti je možné ich rozdelenie na dva týždne alebo spojenie, skrátenie, snažiac sa vyhoviet štruktúre semestra" (Tóth 2019a, 7). Dlíkka jednotlivých kapitol je odlišná, čo z určitého hl'adiska súvisí aj s ich špecifikáciou, a to sa odráža i v našej analýze.

V časti $A$ prvej kapitoly (Úvod do disciplíny sociolingvistiky) sa čitatel' môže oboznámit' s koreňmi a históriou sociolingvistiky ako mladšieho interdisciplinárneho jazykovedného odvetvia, ktoré pochádza z rôznych vedných odborov (najmä zo sociológie, ale aj z antropológie, psychológie atd'.) a súvislosti jazyka a spoločnosti (napr. spoločenské podmienky jazykovej komunikácie, postoje k jazyku, ale aj jazyková politika či jazykové plánovanie) skúma empirickými metódami. Praktická čast' prvej kapitoly je trochu teoretickejšia, ako v ostatných častiach učebnice, lebo poskytuje prehl'ad sociolingvistických výskumov na Slovensku (Ondrejovič 1995, 1996), a zaoberá sa aj pozíciou slovenského jazyka v Mad'arsku (napr. Uhrinová 2008), o ktorej napísal teoreticko-metodologickú štúdiu aj sám autor (Tóth 2008a, $17-30)$.

Druhá kapitola (Metódy sociolingvistického výskumu) sa začína prezentáciou kvantitatívnych a kvalitatívnych výskumných metód sociolingvistiky (pozorovanie, interview, sociometria, sémantický diferenciál atd'.) a poukazuje na to, že každý postup má svoje pozitívne ako aj negatívne stránky, preto je dôležité ich skombinovat'. V praktickej časti sa uvádza použitel'nost' dotazníkového výskumu (Tušková 2016) 
a sú analyzované aj metodologické podobnosti a odlišnosti dialektológie a sociolingvistiky (Ripka 2000). Originálnost' tejto časti zvyšuje skutočnost', že autor sa od r. 2003 sám venuje terénnemu sociolingvistickému výskumu (napr. Tóth 2004, 103 - 110).

Tretia kapitola (Jazykové varianty a stratifikácia jazyka. Sociálna diferenciácia jazyka) sa zaoberá rozvrstvením jazyka (stratifikačná sociolingvistika) a kladie dôraz na zobrazenie jeho jednotlivých variet (variačná sociolingvistika). Nakol'ko variabilita jazyka je centrálnou otázkou sociolingvistiky, čo vyplýva z faktu, že rečové spoločenstvo nie je homogénne, prvá čast' kapitoly poukazuje aj na to, že jedinec v závislosti od komunikačnej situácie môže použivat' rôzne variety toho istého jazyka (dvojjazyčnost', diglosia). Jazykové rozčlenenie charakterizuje nielen jedinca, ale aj celé spoločenstvo, ktoré je jazykovo diferencované. Termíny variantnost' a variabilita autor pokladá za synonymá, napriek tomu, že sa významovo líšia. Pojem variability v jazykovede znamená jav, ked' je jeden samostatný jazykový celok realizovatel'ný v rozličných variáciách (Adger 2006, 503). Prameňom variability je jazyková rozmanitost', ktorá vedie k vzniku rozličných jazykových foriem (Lőrincz 2011, 135). Variabilita teda znamená premenlivost', ktorú môžeme nazývat' aj premenlivou realizáciou (Borbély-Vargha 2010, 455), počas ktorej vznikajú úzko späté jazykové premenné. Variativita oproti variabilite znamená výskyt a funkciu jednotlivých variantov nachádzajúcich sa v synchrónnej jazykovej polohe. Varianty sú jazykové prvky (lexémy, vety), ktoré sú formou vel'mi podobné (vykazujú len čiastočnú rozličnost'), denotatívnym a gramatickým významom sú rovnaké, ale ich pragmatické významy sú odlišné. Táto odlišnost' sa prejavuje v použitel'nosti medzi určitými jazykovými skupinami alebo komunikačnými situáciami (Lőrincz 2009, 110).

Druhá, čiže praktická čast' tretej kapitoly slúži na podrobnejšiu charakteristiku niektorých jazykových variet. Jednou z nich je zmiešaný mestský jazyk (najmä v Bratislave), ktorý okrem prvkov spisovného jazyka zahŕňa v sebe aj prvky rôznych nárečí (Ondrejovič 2008, 234 - 242). Druhými sú tzv. médiolekty, ktoré sa interpretujú spisovnou alebo hovorenou formou jazyka (Mandelíková 2014, 65-67).

Štvrtá kapitola (Kodifikovaná norma a reálne používanie jazyka. Jazyková kultúra, jazyková ideológia) sa v prvom rade venuje analýze spisovného jazyka (čiže kodifikovanej normy), ktorý je kultivovanou formou, najvýraznejšou a najdôležitejšou podobou národného jazyka, čo vznikla na základe potreby jednotného komunikačného prostriedku v období, ked' socioekonomické podmienky vyžadovali bezporuchovú komunikáciu v niektorých sférach života spoločnosti. Podl'a J. Horeckého (1979) národný jazyk má rôzne formy (spisovnú, štandardnú, subštandardnú, nadnárečovú, nárečovú a umeleckú), ktoré tiež majú svoju normu, a tak nemôžeme hovorit' iba o jedinej norme, ale o zložitom normovom systéme (Lőrincz 2009, 92), ktorý je dôležitý z komunikačného hl'adiska a závisí vždy od situácie.

S jazykovou normou úzko súvisia aj jazykové ideológie, čiže „myšlienky a myšlienkové systémy, ktoré slúžia na interpretáciu, odôvodnenie a legitimizáciu faktov týkajúcich sa takých aspektov jazyka a narábania s ním, pomocou ktorých si dominantné spoločenské vrstvy alebo skupiny udržujú moc nad inými vrstvami alebo skupinami“ (Lanstyák 2017, 251). Jazykové ideológie vo vel'kej miere ovplyvňujú názory l'udí ohl'adom rôznych jazykových javov ako aj jazykové správanie hovoriac- 
ich alebo celého rečového spoločenstva k „nesprávne hovoriacim“.

V prvej časti piatej kapitoly (Postoje $k$ jazyku. Jazyková socializácia. Jazyk a vek, jazyk a rod) sa autor sústred'uje na sociologické faktory, ktoré ovplyvňujú použivanie jazyka, čiže na vek, na (biologicky dané) pohlavie a (sociálne konštruovaný) rod, na vzdelanie atd'. Jazykovedu zaujímajú aj demografické poznatky, ako ekonomická aktivita, migrácia, národnost' a pod. Všetky tieto faktory sú extralingválne, napriek tomu značne ovplyvňujú jazykové zmeny. Ako typický spôsob vnútornej migrácie na Slovensku sa dá označit' urbanizácia po II. svetovej vojne, ktorá už v dnešnej dobe nie je až taká silná a ani vonkajšia migrácia sa vo väčšej miere Slovenska nedotýka. Najpočetnejšou národnostnou menšinou na Slovensku je mad'arská menšina, ale aj v Mad'arsku žije okolo tridsat'tisíc Slovákov. Národnostné menšiny majú svoje práva, ktoré im zabezpečujú rámec používania materinského jazyka, ale tejto otázke sa už podrobnejšie venuje jazyková politika (pozri 8. kapitolu). Jazykové postoje Slovákov v Mad’arsku skúmal autor v Slovenskom Komlóši (Tóth 2007, 166 - 171).

Prvá polovica teoretickej časti šiestej kapitoly (Typológia jazykových situácií. Jazyková krajina) sa venuje otázkam jazykovej situácie. Jazyková situácia je súbor jazykov, ktoré existujú popri sebe a navzájom sa doplňujú. Podl'a J. Dolníka (2009, 351 ) tento jav pozostáva z troch zložiek. Prvá je sociálna zložka, ktorá zahŕňa stratifikáciu spoločnosti, ktorú tvoria použivatelia jazyka alebo jazykov. Druhú, komunikačnú zložku predstavujú funkčné a situačné komunikačné sféry. Tretia, jazyková zložka sa vzt́ahuje na jazyky použivané v príslušnom štátnom útvare a ich rozčlenenie na rôzne jazykové útvary. Jazyková situácia môže byt' homogénna (táto forma nie je častá, lebo predpokladá také spoločenstvo, ktoré nie je sociálne stratifikované, žije na pomerne malom území a nemá mnoho členov), môže sa realizovat' ako diglosia (ked' sa vedl'a seba na určitom mieste a v tom istom čase uplatňujú dva varianty toho istého jazyka, ktoré sa lišia vo funkcii, v miere štandardizácie atd'.), alebo ako dvoj- a mnohojazyčnost'. Jazyková situácia má tri dimenzie: vnútrojazykový rozmer (jednotlivé existenčné formy národného jazyka), medzijazykový rozmer (spoločenské postavenie, kultúra a vyučovanie slovenského národného jazyka vo vzt'ahu k jazykom, s ktorými majú príslušníci slovenského národa aktívne kontakty), mimojazykový rozmer (spoločenské, politické a kultúrne činitele vplývajúce na stav jazyka a jeho použivanie).

Druhá polovica teoretickej časti šiestej kapitoly sa zaoberá tematikou jazykovej krajiny, ktorá sa definuje ako ,jazyk verejného dopravného značenia, reklamných bilbordov, názvov ulíc, názvov miest, jazyk komerčných označení názvov obchodov a štátnych budov" (Landry-Bourhis 1997, 25). Koncepcia jazykovej krajiny zahŕňa pohl'ad na pestrost' spoločnosti, politické ideológie, ako aj na použivanie jazyka. Ako výskumná metóda medziiným čerpá zo sociolingvistiky, semiotiky, folkloristiky, histórie, práva, geografie, onomastiky, ekonómie, psychológie atd'. (Mensel-Vandenbroucke-Blackwood 2016, 423).

Praktická čast' tejto kapitoly sa tiež sústred'uje na jazykovú krajinu a kladie dôraz na výskumy prezentujúce stav rôznych regiónov Slovenska, ktoré obývajú rozdielne etnicko-jazykovo-kultúrne spoločenstvá (napr. zmiešané pohraničné oblasti). V medzinárodnom kontexte sa skúmaním jazykovej krajiny južného Slovenska okrem 
iných zaoberali E. Győriová Baková (2015), M. Satinská (2014), a M. Sloboda (2009).

Siedma kapitola (Bilingvizmus) sa zaoberá dvojjazyčnost'ou, ktorá je vel'mi zložitý jazykový jav, a preto má viacero definícií. Jednou z najpoužívanejších je tá, podl'a ktorej bilingvizmus je kompetencia alternatívneho použivania dvoch jazykov v závislosti od konkrétnej situácie, v ktorej komunikácia prebieha. Ak chceme definovat' bilingvizmus presnejšie, musíme brat' do úvahy dva pohl'ady, a to monolingválny a holistický. Prvý chápe bilingvistu ako dvoch monolingvistov v jednej osobe, čiže jazykové kompetencie dvojjazyčného človeka porovnáva s kompetenciami monolingvistu. Podl'a druhého bilingvista nemá ( $a$ ani nemôže mat') také isté kompetencie v oboch jazykoch, a preto sa nesmie porovnávat' s monolingvistom. Dvojjazyčnost' je prirodzený jav, lebo väčšina populácie sveta je do istej miery bilingválna, čo sa týka aj Mad'arov žijúcich na juhu Slovenska.

Praktická čast' siedmej kapitoly je venovaná slovenským a mad'arským bilingválnym národnostným menšinám (pozri aj najnovšie výskumné výsledky autora: Tóth 2019b, 25 - 39; 2020, 227 - 235). Napriek tomu, že na Slovensku je mad'arčina menšinovým jazykom, na juhu krajiny sú mestá, kde väčšinu obyvatel'stva tvoria Mad'ari. To znamená, že v takýchto prípadoch jazykovou menšinou sú Slováci. Takým mestom bolo v minulosti a ( $v$ istej miere) je aj dnes Komárno, kde slovenčinu podl'a pôvodu možno zadelit' do troch foriem: v prvom rade slovenčina presidlencov, v druhom tzv. komárňanská slovenčina, a nakoniec slovenčina pristáahovalcov (Šmelík 2007).

Predposledná čast' knihy (Jazyková politika a jazykové právo, jazykový manažment a plánovanie) sa týka takých tém, ktoré sú nevyhnutné v živote národnostných menšín. Jazykové plánovanie je zámerná regulačná činnost' v oblasti jazyka, ktorú realizuje štát prostredníctvom svojich inštitúcií, organizácii alebo istých autoritatívnych subjektov. Jazykové plánovanie má tri čiastkové podoby. Statusové plánovanie sa týka medziiným funkcií jazykov (ktorý bude napr. štátnym - majoritným a ktorý menšinovým), korpusové plánovanie sa zaoberá podobou jednotlivých variet alebo jazykov (patrí sem napr. vytváranie terminológie v danom jazyku, resp. $v$ danej variete) a akvizičné plánovanie sa sústredí na možnosti prístupu $\mathrm{k}$ jazykom. S jazykovým plánovaním tesne súvisí aj jazyková politika. Tieto termíny sa v stredoa východoeurópskej lingvistike líšia významom, ale v západoeurópskej a americkej jazykovede sa používa iba pojem language planning, čiže vnímajú ich ako synonymá. Jazyková politika je súhrn aktivit, ktorými sa regulujú podmienky na fungovanie jazykov a jazykových variet koexistujúcich v danom politickom útvare (Dolník 2009, 351 - 352). Jazyková politika môže byt' podl'a zamerania retrospektívna alebo perspektívna, podl'a etnickej orientácie internacionalistická a nacionalistická (Mandelíková 2014, 95) a podl'a toho, u koho sa sústred'uje jazykovo-politická moc, sa delí na centralizovanú a decentralizovanú.

Praktická čast' tejto kapitoly sa venuje otázkam jazykovej politiky na Slovensku. S. Ondrejovič sa v jednom príspevku zamýšla nad potrebou ochrany slovenčiny ukotvenej legislatívne a konštatuje: „Mali by sme našej slovenčine dovolit', aby bola sama sebou, aby bola prirodzene rozmanitá, mnohotvárna a mnohofarebná, aby bola tisícoraká či dokonca občas aj hýrivá." (Ondrejovič 2009, 40). Napriek tomu 
Slovenská republika má 17 zákonov, v ktorých sú sformulované jazykové práva osôb patriacich k národnostnej menšine (Szabómihály 2006, 44; Misad 2012). Tie opatrenia sú v mnohých prípadoch sporné, lebo napr. zákon o použivaní jazykov národnostných menšín (184/1999 Z. z.) v úvodnej časti vyhlasuje, že význam materinských jazykov občanov Slovenskej republiky patriacich k národnostným menšinám sa uznáva a oceňuje ako prejav kultúrneho bohatstva štátu, napriek tomu regulácia použivania tých jazykov je potrebná zákonným rámcom.

Posledná, deviata kapitola (Jazyk a edukácia v súvislosti s viacjazyčnostou) z rôznych aspektov skúma súvislosti viacjazyčnosti a edukácie. Autor poukazuje na to, že slovenčina v Mad'arsku má inú pozíciu ako mad'arčina na Slovensku a z toho vyplýva, že inak vyzerá aj menšinové školstvo v obidvoch štátoch. Kým na Slovensku má mad'arská národnost' svoje inštitúcie od materskej školy až po univerzitu, Slováci v Mad'arsku nemajú vlastnú univerzitu alebo vysokú školu, ale na rôznych významných univerzitách (v Segedíne, v Budapešti, v Ostrihome) fungujú katedry slovenského jazyka a literatúry integrované do národnostného alebo slavistického inštitútu. Silnú stránku autorovej výskumnej činnosti predstavuje slovenské školstvo v Mad'arsku (Tóth 2008b, 2012b), avšak mohol by venovat' väčšiu pozornost' aj súvislostiam bilingvizmu a diglosie vo vyučovacom procese, lebo jazykové kompetencie žiakov mad'arskej národnosti (nielen na Slovensku, ale aj v Rumunsku, v Srbsku atd'.) sa lísia od kompetencií mad'arských monolingválnych žiakov. Tento fakt sa prejavuje jednak v tom, že deti vo viacerých prípadoch namiesto štandardnej formy mad'arčiny použivajú také variety, na ktoré majú vel'ký vplyv rôzne nárečia a okrem toho zahŕňajú v sebe aj prevzaté slová zo slovenčiny a kalky. Preto je potrebné, aby si deti mad'arskej národnosti uvedomili, že ich jazyk je iný, ako štandardná mad'arčina, ale to neznamená, že by bol horší. Z toho dôvodu by jednou z najdôležitejších úloh menšinového školstva bolo to, aby učitelia poukázali na odlišnosti dvoch variet a pritom aplikovali kontrastívny názor a iný postoj, ako v monolingválnom prostredí. Praktická čast' poslednej kapitoly je zameraná na výskum (Simon 2017), ktorý sa sústred'uje na písané jazykové prejavy študentov v školách s vyučovacím jazykom mad'arským. Z jednej strany sa absolventom stredných škôl s VJM často vyčía, že nevedia dokonale po slovensky, ale z druhej strany platí, že mladým, ktorí pokračujú $v$ štúdiu na slovenských vysokých školách a univerzitách, nerobí problém nadobudnút odborné vzdelanie v slovenskom jazyku. Napriek tomu, samozrejme, nemôžeme tvrdit', že situácia vo vyučovaní slovenského jazyka na školách s VJM je ideálna: žiaci vo všeobecnosti majú najväčšie problémy so slovosledom, použitím slovesných väzieb a štylizáciou.

\section{Didaktický prínos elektronických materiálov}

K horeuvedenej učebnici patrí aj CD (Győriová Baková-Simon 2019), na ktorom sa nachádzajú prezentácie k jednotlivým kapitolám s ilustráciami, slúžiace ako podklad na individuálne doplnenie. Prednášajúci pedagóg ich môže spojit' so svojimi existujúcimi prezentáciami alebo ich doplnit' vlastnými výsledkami výskumu z danej oblasti. Elektronické študijné materiály sa v dnešnej dobe (a najmä v posledných 
mesiacoch, počas koronakrizy) stávajú nevyhnutnou súčastou vyučovacieho procesu, a preto powerpointové prezentácie na $C D$ sú užitočnými pomôckami pre učitel'ov pri vyučovaní, lebo takýmto spôsobom môžu študentom podat' učebnú látku transparentnejšie, názornejšie. Okrem toho sú dané elektronické materiály užitočné aj pre samotných študentov, ktorým na jednej strane zjednodušia percepciu učebnej látky a na druhej strane im pomôžu l'ahšie sa pripravit' na skúšky. Súčastou CD a knihy je aj bohatá, tematicky členená bibliografia, pomocou ktorej učitelia a študenti môžu lepšie spoznat' rôzne aspekty jednotlivých tém. Nejde teda o zvyčajný zoznam použitej literatúry, ale o taký, ktorý ponúka možnost' d'alšieho prehíbenia pri skúmaní sociolingvistických otázok.

\section{Záver}

Na záver sa sem dokonale hodia myšlienky autora skúmanej knihy Sociolingvistika v slovensko-mad'arskom kontexte: „Predkladanú učebnicu venujeme študentom slovakistiky na pedagogických a filozofických fakultách, najmä v kontaktných zónach slovenského jazyka od Prahy po Nový Sad a Viedeň, resp. od Komárna po Segedín, a veríme, že bude osožná i pre záujemcov o tému na celom Slovensku“ (Tóth 2019a, 9). K tomu môžeme ešte pridat', že skúmaná kniha a elektronické materiály môžu byt' užitočné aj pre poslucháčov katedier mad'arského jazyka a literatúry na Slovensku, lebo rozpracovaná tematika sa sústred'uje na také otázky, ktoré sa vztahujú aj na ich každodennú jazykovú skutočnost'. Aj z citácií je zrejmé, že použitel'nost' skúmanej knihy je mnohostranná, a preto by sme boli radi, aby jej prijatie bolo pozitívne, aj aby ju na rôznych slovenských a mad'arských univerzitách použivali pri vyučovaní sociolingvistiky $v$ čo najväčšej miere.

\section{Literatúra}

Adger, David (2006): Combinatorial Variability. Journal of Linguistics 42/3, 503-530. p. Blommaert, Jan (2012): Chronicles of complexity. Etnography, superdiversity and linguistic landscapes. Tilburg: Tilburg University.

Borbély, Anna - Vargha, András (2010): Az I variabilitása öt foglalkozási csoportban. Kutatások a Budapesti Szociolingvisztikai Interjú beszélt nyelvi korpuszban. Magyar Nyelv 106/4, 455-470. p.

Dolník Juraj (2009): Všeobecná jazykoveda. Bratislava: VEDA.

Győriová Baková Eva (2015): Language situation in Komárno. In Transboundary Symbiosis over the Danube (Part II): Road to a Multidimensional Ethnic Symbiosis in the Mid-Danube Region. Eds. Osamu, leda - Susumu, Nagayo. Sapporo: Slavic-Eurasian Research Center, Hokkaido University. 161-174. p.

Győriová Baková Eva - Simon Szabolcs (2019): Sociolingvistika v slovensko-mad'arskom kontexte. Elektronické študijné materiály. Komárno: Univerzita J. Selyeho. 
Horecký, Ján (1979): Východiská k teórií spisovného jazyka. In Z teórie spisovného jazyka. Eds. Eds. Ružička Jozef - Kačala Ján. Bratislava: VEDA, 13-22. p.

Kováčová, Viera (2013): Vybrané kapitoly z dialektológie. Ružomberok: VERBUM-Vydavatel'stvo Katolíckej univerzity v Ružomberku.

Landry, Rodrigue - Bourhis, Richard (1997): Linguistic landscape and ethnolinguistic vitality: An empirical study. Journal of Language and Social Psychology 16/1, 23-49.

Lanstyák, István (2017): Jazykové ideológie. Všeobecné otázky a glosár. In Jazyk a jazykové ideológie v kontexte viacjazyčnosti na Slovensku. Eds. Lanstyák, István - Múcsková Gabriela - Tancer Jozef. Bratislava: Filozofická fakulta Univerzity Komenského, 251 -307. p. Lőrincz, Julianna (2009): Nyelvi jelentés és variativitás. Szemantikai alapismeretek. Komárom: Selye János Egyetem.

Lőrincz, Julianna (2011): A variánsok helye és funkciója a magyar nyelvben. In Kommunikáció - Stílus - Variativitás és anyanyelvoktatás. Pandora Könyvek 24. Eger: EKF Líceum Kiadó, 135-141. p.

Mandelíková Lenka. (2014): Sociokultúrne súvislosti jazyka. Trenčín: Trenčianska univerzita Alexandra Dubčeka v Trenčíne, Fakulta sociálno-ekonomických vzt'ahov.

Misad, Katalin (2012): Nyelvtörvények tükrében. In A tudomány vonzásában. Köszöntő kötet a 70 éves Vörös Ottó tiszteletére. Eds. Simon, Szabolcs - Török, Tamás. Komárno: Univerzita J. Selyeho, 69-83. p.

Ondrejovič Slavomir (1995): Sociolingvistické aspekty jazykovedného výskumu na Slovensku. In Sociolinguistica Slovaca 1: Sociolingvistické aspekty výskumu súčasnej slovenčiny. Eds. Ondrejovič Slavomír - Šimková Mária. Bratislava: VEDA, 9-13. p.

Ondrejovič Slavomír (1996): Metamorfózy sociolingvistického výskumu na Slovensku In Sociolinguistica Slovaca 2: Sociolingvistika a areálová lingvistika. Ed. Ondrejovič Slavomír. Bratislava: VEDA, 11-17. p.

Ondrejovič Slavomír (2008): Jazyk, veda o jazyku, societa. Sociolingvistické etudy. Bratislava: VEDA, 234-242.

Ondrejovič Slavomír (2009): Slovenčina - skleníková rastlina? In Slovo. Tvorba. Dynamickost'. Ed. Šimková Mária. Bratislava: VEDA, 38-41. p.

Simon, Szabolcs (2017): Jazykové premenné v písaných variantoch mad'arského jazyka na Slovensku a ich výučba. In Jazyk a politika. Na pomedzí lingvistiky a politológie 2. Ed. Štefančík Radoslav. Bratislava: Ekonóm, 449-464. p.

Šmelík Ĺudovit (2007): Výskum v Komárne a Topol'čianskom okrese. In Sociolinguistica Slovaca 6: Hovorená podoba spisovnej slovenčiny. Ed. Ondrejovič Slavomír. Bratislava: VEDA, 153-166. p.

Satinská Lucia (2014): Jazyková krajina Bratislavy: Dunajská ulica. In Polarity, paralely a prieniky jazykovej komunikácie. Ed. Patráš Vladimír. Banská Bystrica: Belianum, 157-167. p.

Sloboda Marián (2009): State ideology and linguistic landscape: A comparative analysis of (post)communist Belarus, Czech Republic and Slovakia. In Linguistic Landscape: Expanding the Scenery. Eds. Shohamy, Elana - Gorter, Durk. New York-London: Routledge, 173-188. p.

Szabómihály, Gizella (2006): A szlovák nyelvpolitika és a kisebbségek anyanyelvhasználati lehetlehetöségei és törekvései. Romániai magyar jogtudományi közlöny 2006/2, 43-49. p. 
Tóth Sándor János (2004): Pitvaroš, Albert, Ambróz - školstvo a cirkev. In Slovenčina $v$ menšinovom prostredí. Eds. Uhrinová Alžbeta - Žiláková Mária. Békešská Čaba: Výskumný ústav Slovákov v Mad'arsku, 103-110. p.

Tóth Sándor János (2007): Postoj k dvojjazyčnosti v Slovenskom Komlóši In Aktuálne problémy slovakistiky. Ed. Žiláková Mária. Budapest: ELTE BTK, 166-171. p.

Tóth Sándor János (2008a): Teoretické a metodologické východiská výskumu slovenského jazyka v Mad'arsku. In Slovenský jazyk v Mad’arsku I. Eds. Uhrinová Alžbeta - Žiláková Mária. Békéscsaba: Výskumný ústav Slovákov v Mad'arsku, 17-30. p.

Tóth Sándor János (2008b): Slovenčina v školách v Mad'arsku. Slováci v zahraničí 25. Martin: Matica slovenská, 161-181. p.

Tóth Sándor János (2012a): Germanizmy v slovenčine - sociolingvistický výskum v Ružomberku. In Brněnská hungaroslavistika a česko-slovensko-mad’arské vztáahy. Ed. Käfer István - Pospišil Ivo. Szeged: Gerhardus Kiadó, 139-156. p.

Tóth Sándor János (2012b): Slovenské školstvo v Mad'arsku - integrácia a segregácia. Studia Scientifica Facultatis Paedagogicae 4. (X.), 48-70. p.

Tóth Sándor János (2019a): Sociolingvistika v slovensko-mad'arskom kontexte. Komárno: Pedagogická fakulta, Univerzita J. Selyeho.

Tóth Sándor János (2019b): The dominant language of bilingual speakers in South Slovakia. Berliner Beiträge zur Hungarologie 2019/20, 25-39. p.

Tóth Sándor János (2020): The impact of Hungarian on Slovak language use in bilingual milieu. Yearbook of Finno-Ugric Studies / Ежегодник финно-угорских исследований 14/2, 227-235. p.

Tušková Tünde (2016): Slovenský jazyk v univerzitnom bilingválnom prostredí. Békešská Čaba: VúSM.

Ripka Ivor (1996): Ďalšie smerovanie teritoriálnych výskumov. In Sociolinguistica Slovaca 2: Sociolingvistika a areálová lingvistika. Ed. Ondrejovič Slavomír. Bratislava: VEDA, 18-24. p.

Uhrinová Alžbeta (2008): Najdôležitejšie faktory zachovania slovenského jazyka v Mad'arsku. In Slovenčina v menšinovom prostredí II. Eds. Uhrinová Alžbeta - Tóth János. Békešská Čaba: VúSM, 71-88. p.

Van Mensel, Luk - Vandenbrouke, Mieke - Blackwood, Robert (2016): Linguistic Landscapes. In Oxford Handbook of Language and Society. Eds. Garcia, Ofelia - Flores, Nelson - Spotti, Massimiliano. Oxford: Oxford University Press, 423-449. p. 